\title{
Cardiac rupture complicating acute myocardial infarction: the clinical features from an observational study and animal experiment
}

\author{
Qun Lu ${ }^{1 *}$, Ping Liu', Jian-Hua Huo ${ }^{1}$, Yan-Ni Wang ${ }^{1}$, Ai-Qun Ma ${ }^{1}$, Zu-Yi Yuan ${ }^{1}$, Xiao-Jun Du ${ }^{2,3^{*}}$ and Ling Bai ${ }^{1}$
}

\begin{abstract}
Background: Cardiac rupture (CR) is a fatal complication of ST-elevation myocardial infarction (STEMI) with its incidence markedly declined in the recent decades. However, clinical features of CR patients now and the effect of reperfusion therapy to $C R$ remain unclear. We investigated the clinical features of CR in STEMI patients and the effect of reperfusion therapy to $C R$ in mice.

Methods: Two studies were conducted. In clinical study, data of 1456 STEMI patients admitted to the First Hospital, Xi'an Jiaotong University during 2015.12. 2018.12. were analyzed. In experimental study, 83 male C57BL/6 mice were operated to induce MI. Of them, 39 mice were permanent MI (group-1), and remaining mice received reperfusion after $1 \mathrm{~h}$ ischemia (21 mice, group-2) or $4 \mathrm{~h}$ ischemia (23 mice, group-3). All operated mice were monitored up to day-10. Animals were inspected three times daily for the incidence of death and autopsy was done for all mice found died to determine the cause of death.

Results: CR was diagnosed in 40 patients: free-wall rupture in 17, ventricular septal rupture in 20, and combined locations in 3 cases. CR presented in 19 patients at admission and diagnosed in another 21 patients during $1 \sim 14$ days post-STEMI, giving an in-hospital incidence of 1.4\%. The mortality of CR patients was high during hospitalization accounting for 39\% of total in-hospital death. By multivariate logistic regression analysis, older age, peak CK-MB and peak hs-CRP were independent predictors of CR post-STEMI. In mice with non-reperfused MI, 17 animals (43.6\%) died of CR that occurred during 3-6 days post-MI. In MI mice received early or delayed reperfusion, all mice survived to the end of experiment except one mouse died of acute heart failure.
\end{abstract}

Conclusion: CR remains as a major cause of in-hospital death in STEMI patients. CR patients are characterized of being elderly, having larger infarct and more server inflammation. Experimentally, reperfusion post-MI prevented CR.

Keywords: Cardiac rupture, Acute myocardial infarction, Sudden cardiac death, Prognosis, Risk factor, Reperfusion

\footnotetext{
*Correspondence: luqun00@163.com; xiao-jun.du@baker.edu.au

'Department of Cardiovascular Medicine, First Affiliated Hospital, School of

Medicine of Xi'an Jiaotong University, No.277 Yanta West Road, Xi'an, Shaanxi

710061, P.R. China

2Experimental Cardiology Lab, Baker Heart and Diabetes Institute, 75

Commercial Road, Melbourne, Victoria 3004, Australia

Full list of author information is available at the end of the article
}

(C) The Author(s). 2020 Open Access This article is licensed under a Creative Commons Attribution 4.0 International License, which permits use, sharing, adaptation, distribution and reproduction in any medium or format, as long as you give appropriate credit to the original author(s) and the source, provide a link to the Creative Commons licence, and indicate if changes were made. The images or other third party material in this article are included in the article's Creative Commons licence, unless indicated otherwise in a credit line to the material. If material is not included in the article's Creative Commons licence and your intended use is not permitted by statutory regulation or exceeds the permitted use, you will need to obtain permission directly from the copyright holder. To view a copy of this licence, visit http://creativecommons.org/licenses/by/4.0/ The Creative Commons Public Domain Dedication waiver (http://creativecommons.org/publicdomain/zero/1.0/) applies to the data made available in this article, unless otherwise stated in a credit line to the data. 


\section{Background}

Cardiac rupture (CR) consists of free wall rupture (FWR) and ventricular septum rupture (VSR), and is a lethal mechanical complication of acute myocardial infarction (MI) [1], the incidence of CR was between 7 to $20 \%$ in ST-elevation MI (STEMI) patients during 1970s to 1990 s [2, 3], when CR was reported to occur either early after the onset of MI (type I or II, approximately $55 \%)$ or during the sub-acute phase accompanied with overt cardiac remodeling (type III, 45\%) [3]. Factors including old age [4], female gender [4], and large infarct size [2] were found to be associated with the risk of CR. With the routine use of thrombolytic drugs and revascularization therapy including percutaneous coronary intervention (PCI), the incidence of CR has decreased to the current approximately $1 \%[3,5]$, attributable to thrombolytic [6, 7] and reperfusion therapies [1]. Primary PCI (pPCI) as the standard treatment for MI has also remarkably reduced the in-hospital mortality and improved the long-term outcomes.

Nevertheless, current literature indicates that CR remains as an emergency of modern cardiology contributing to the total in-hospital mortality in MI patients [3]. It is unclear on the clinical features of CR in the era of reperfusion therapy, a knowledge essential for the evaluation and timely intervention of CR events and preventive procedures. There has been lack of evidence for a causal relationship between reperfusion therapy and reduced risk of CR. Accordingly, the aim of this study was to investigate the incidence, associated risk factors, timing of occurrence, and clinical outcomes of this complication in acute MI patients in the PCI era and influence of reperfusion in MI mice.

\section{Methods}

This study was done within both MI patients and animal experiments.

\section{Patients with acute MI}

A retrospective medical record review study was conducted using the electronic patient record system of the First Affiliated Hospital of Xi'an Jiaotong University in Shaanxi province. We screened the records of patients who were admitted to the CCU of the study hospital during December 2015 and December 2018 and identified patients with ST-elevation MI (STEMI). Exclusion criteria included patients with non-STEMI, unstable angina, or recent or remote MI. This protocol was approved by the ethics committee of the First Affiliated Hospital of Xi'an Jiaotong University (Shaanxi 710,061, China) and was in accordance with the Helsinki Declaration's guidelines. Informed consent was obtained for all participants and families.

\section{Animals}

Male C57BL/6 mice were introduced from Jackson Laboratory (USA) and used at the age of 12-15 weeks. Mice were housed in standard conditions with food and water provided ad libitum in a $12 \mathrm{~h} / 12 \mathrm{~h}$ light/dark cycle. All procedures used were approved by a local animal ethics committee in compliance with the Australian Code for the Care and Use of Animals for Scientific Purposes (8th edition) and the ARRIVE guidelines.

Mice were anesthetized using the mixture of ketamine/xylazine/atropine $(20 / 100 / 1.2 \mathrm{mg} / \mathrm{kg}$, respectively) and put on a heated pad. As we previously described [8], open-chest surgery was done to induce coronary artery occlusion (CAO). Animals were randomized into 3 groups subjecting to either permanent CAO (group-1), ischemia-reperfusion (IR, group -2 and -3 ). Reperfusion was done following CAO lasting $1 \mathrm{~h}$ (group-2) or 4 $\mathrm{h}$ (group-3). All operated mice were monitored up to day-10. Animals were inspected three times daily for the incidence of death and autopsy was done for all mice found died to determine the cause of death. After this study, all mice were euthanized with pentobarbital overdose and autopsied to confirm presence of MI.

To get insight into influence by reperfusion on CR risk, we measured infarct size in a separate batch of mice. Mice were operated to induce CAO and then randomly allocated into 3 groups subjected to nonreperfused MI or IR after an ischemic period of $1 \mathrm{~h}$ or 4 h. Infarct size was determined $48 \mathrm{~h}$ post-surgery using the established dual-staining method, as we previously described [9]. In brief, at the end of reperfusion, the heart was injected via aortic cannulation with $5 \%$ Evans blue, followed by sections of the left ventricle $(1 \mathrm{~mm}$ in thickness) and staining with $1.5 \%$ triphenyltetrazolium chloride (TTC, $30 \mathrm{~min}, 37^{\circ} \mathrm{C}$ ). Images of LV sections were acquired digitally and the risk zone and infarct zone were determined using Image J software and infarct size was expressed as percentage of risk zone.

\section{Diagnosis of ST-elevation myocardial infarction}

According to the AHA/ACCA [10] and ESC [11] guidelines for STEMI patients, diagnosis of STEMI was based on the concurrence of chest pain or symptoms compatible with acute heart failure or unexplained syncope, STsegment elevation $\geq 1 \mathrm{~mm}$ in 2 inferior or lateral leads or $\geq 2 \mathrm{~mm}$ in $\geq 2$ precordial leads and elevation of cardiac biomarkers (CK-MB or troponin-T).

\section{Diagnosis of cardiac rupture}

Among STEMI patients, sing CCU-quipped Phillips iE33 system, echocardiography was performed at day-1 after admission, as well as before hospital discharge or when the following conditions were observed during the infarct evolution: hypotension, syncope, chest pain, ECG 
changes, severe arrhythmias or conduction disturbances. Patients were placed on supine or on left recumbent position. 2-Dimensional echocardiograms were acquired using Phillips iE33 ultrasound system with S5-1 probe. Images were obtained in the standard parasternal longand short-axes, apical and subcostal 4-chamber views. Color-Doppler echocardiography was used in conjunction with 2-dimensional echocardiography. All images were recorded on videotape and analyzed by at least two echocardiography specialists. Diagnosis of CR was based on echocardiographic findings and clinical manifestations. FWR was diagnosed by the presence of echo-signal free space of the free wall myocardium or presence of pericardial effusion (Fig. 1a and b), Color Doppler detected blood flow shunt between the ventricle and the pericardium (Fig. 1b) when patients developed sudden onset of cardiogenic shock, conscious disturbance, and pulseless electric activity (electromechanic dissociation) after being in a stable condition [12]. VSR was suggested by physical examination of strong cardiac murmur and diagnosed by echocardiography as presence of echo signal-free pace of the ventricular septum (Fig. 1c and d) and Color Doppler detected blood flow signal across the ventricular septum (Fig. 1d) [12].
In animal study, CR diagnosis was confirmed by autopsy findings of presence of a large amount of blood clot around the heart and in the chest cavity, a perforation of the infarcted wall [8].

\section{Clinical measurements}

Investigators and a trained interviewer collected all the clinical data. Potential predictive variables evaluated in this study included demographic characteristics (age and sex), classical cardiovascular risk factors (smoking, hypertension, diabetes mellitus and alcohol consumption), characteristics of MI (localization, culprit artery, numbers of diseased vessels) and Killip's classification. Smoking was defined as smoking cigarettes within 1 month of the index admission. Alcohol consumption was defined as drinking $>30 \mathrm{~mL}$ ethanol per day in men and $>15 \mathrm{~mL}$ ethanol per day in women. Hypertension was defined as a cuff blood pressure $\geq 140 / 90 \mathrm{mmHg}$ and/or the current use of antihypertensive medications. Diagnosis of diabetes was confirmed as plasma fasting glucose was $\geq 7.0 \mathrm{mM}$ (or the 2-h postprandial glucose was $>11.1 \mathrm{mM}$ ) and /or there was current use of antidiabetic medication. Killip classification was assigned for the presence and severity of heart failure for STEMI patients according to AHA/ACCA [10] and ESC
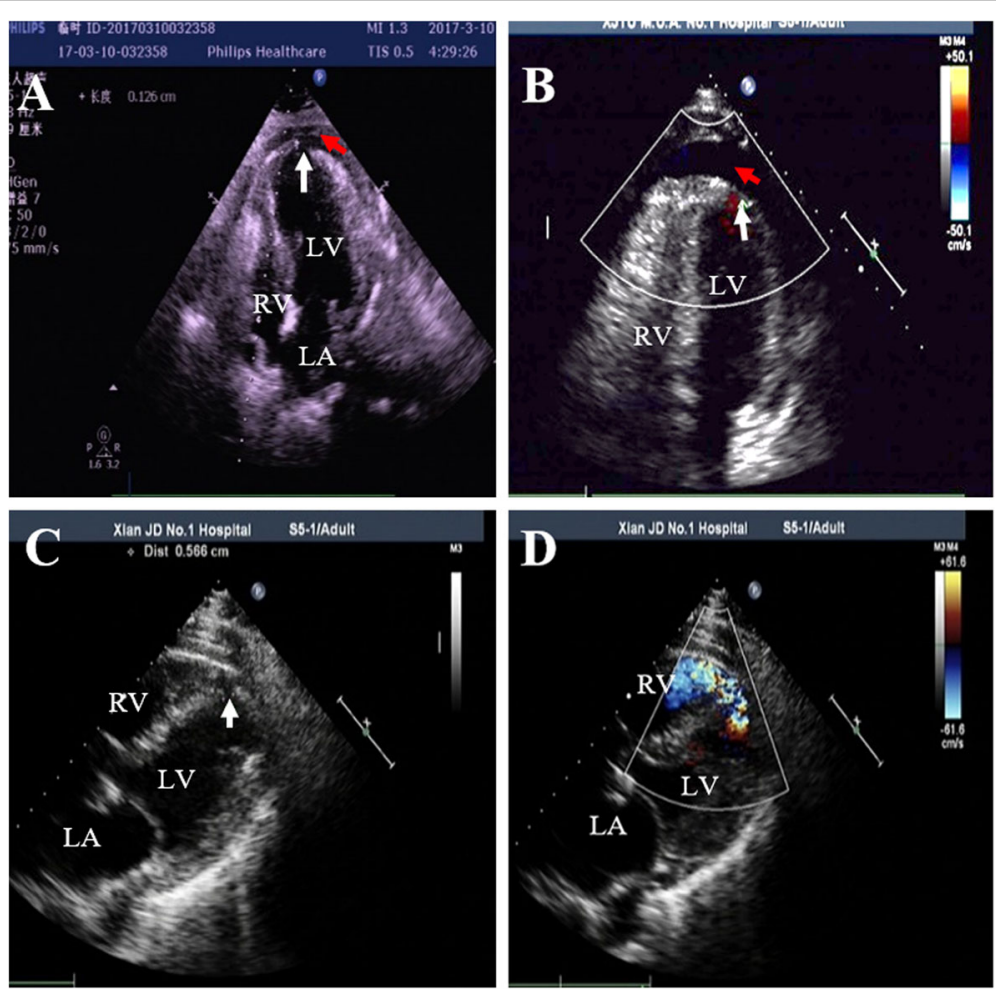

Fig. 1 Representative transthoracic echocardiographic images from patients with cardiac rupture. a 2-D image revealed discontinuity of the left ventricular (LV) wall (white arrow) and pericardial effusion (red arrow). b Color Doppler image demonstrated shunting of blood flow from the LV to the pericardium (white arrow) and presence of pericardial effusion (red arrow). c ventricular septum discontinuity (white arrow) in 2-D image. d shunting of blood from the LV to the right ventricle (RV, red arrow) in Color Doppler image; $L A=$ left atrium; $R A=$ right atrium 
guideline [11]. Infarct location was determined by electrocardiogram and echocardiography. Selective coronary angiograms were obtained using the Judkins or Sones technique. The coronary arteries were analyzed by routine angiogram. On the basis of luminal stenosis $\geq 50 \%$ as significant coronary stenosis, the number of coronary arteries with lesion was determined. Information also included socio-economic features of patients as resident of urban or countryside. Surrounding country-level regions, including counties and county-level cities, were then designated as rural area.

\section{Laboratory parameters}

For measurements of hemoglobin (HB), blood cell counts or high-sensitivity C-reactive protein (hs-CRP), blood was collected via the median cubical vein using EDTA-containing tubes at admission and daily afterwards. HB, white blood cell (WBC) and neutrophils were measured with automated cell counters via standard techniques by HST201 (Sysmex, Japan). hs-CRP was measured by high-sensitivity particle-enhanced immunoturbidimetric method using BN II (Siemens, Germany). Blood was also drawn into sodium citrate-containing tubes, at admission and then daily after a 12-h overnight fasting for measurements of fibrinogen, D-dimer and fibrinogen degradation products (FDP), by using the latex agglutination test (Sysmex CA - 7000, Sysmex, Japan). To detect the peak of creatine kinase-MB (CK-MB), blood was collected into tubes containing no anticoagulant at admission and then every $6 \mathrm{~h}$ after symptom onset for $24 \mathrm{~h}, \mathrm{CK}-\mathrm{MB}$ were determined by the spectrophotometric method using the Olympus AU640 Clinical Chemistry analyzer (Olympus Diagnostica, Hamburg, Germany).

\section{Treatment and evaluation of patient outcomes}

All patients were administered loading doses of aspirin $300 \mathrm{mg}$ and clopidogrel $600 \mathrm{mg}$ or ticagrelor $180 \mathrm{mg}$, followed by maintenance doses of aspirin $100 \mathrm{mg}$, clopidogrel $75 \mathrm{mg}$ or ticagrelor $180 \mathrm{mg}$ daily. All patients received $\beta$-blockers, angiotensin converting enzyme inhibitors (ACEI) or angiotensin receptor blockers (ARB) and statins according to the AHA/ACCA [10] and ESC STEMI guidelines [11], unless there were contraindications to these drugs. All patients were administered pPCI or delay PCI based on clinical manifestation according AHA/ACCA [10] and ESC STEMI guidelines [11]. All CR patients were suggested equally to reperfusion, intra-aortic balloon pumping (IABP), extracorporeal membrane oxygenation (ECMO), percutaneous closure or surgical repair, if patients had not contraindications. The primary outcome was mortality, defined as deaths of any cause in-hospital or within 60 days. Inhospital mortality was obtained from hospital medical records. Patients were also followed up for information of 60-day mortality by interview or telephone communication with these patients or their families.

\section{Statistical analyses}

Analyses were performed using SPSS version 13.0. Normally distributed values are presented as mean \pm SD, and differences between groups were determined using ANOVA followed by Student's t-test. Variables with a skewed normal distribution are presented as medians (interquartile range), and between-group differences for these variables were determined using Rank-Sum test. Categorical variables are presented as percentages, and the differences between groups were tested using Chisquare test. The logistic model was used to evaluate the associations between cardiac rupture and variables. Odds ratios (OR) and 95\% confidence intervals (CI) were calculated. Survival estimates were generated using KaplanMeier method. Significance was defined at the 5\% level using a two-tailed test.

\section{Results \\ Incidence and time-course of cardiac rupture}

During December 2015 to December 2018, a total of 5844 consecutive patients were admitted to the CCU. Of them, 2568 patients were excluded according to the exclusion criteria and the remaining 1456 patients with confirmed STEMI diagnosis were included in this retrospective study. There were 40 patients diagnosed with CR (Table 1), VSR occurred in 20 cases, FWR in 17 cases and combined location in 3 cases. 19 patients had $\mathrm{CR}$ before arriving the hospital with estimated symptom-to-CR interval of $4 \mathrm{~h}$ to 15 days. CR occurred within hospital in 21 patients giving the in-hospital incidence of CR 1.4\% (21/1456). In 9 patients CR developed post-pPCI, and 2 cases received thrombolytic therapy. As shown in Fig. 2, 18 patients (45\%) developed CR within $24 \mathrm{~h}$ after chest pain symptoms onset. And $16 \mathrm{pa}-$ tients (40\%) occurred CR during 2-6 days after symptoms onset, and another CR occurred in another $4(10 \%)$ patients during 7-15 days after STEMI.

\section{Characteristics of cardiac rupture}

Relevant patient baseline characteristics are summarized in Table 2. $45 \%$ of $\mathrm{CR}$ patients admitted to hospital within $12 \mathrm{~h}$ whilst $12.5 \%$ of CR patients arrived to hospital during 12-24 $\mathrm{h}$ after the onset of symptom, and the ratio of patients who arrived to hospital within $12 \mathrm{~h}$ after symptom was higher in CR patients than CR-free patients (Table 2).

Patients with CR were older, more likely to be female and had history of hypertension and/or diabetes mellitus and lower blood pressure (Table 2). CR groups also had lower incidence of previous MI and previous PCI (Table 
Table 1 Clinical characteristics of cardiac rupture

\begin{tabular}{|c|c|c|c|c|c|c|c|c|c|c|c|c|}
\hline Case & gender & Age (y) & $\begin{array}{l}\text { Location } \\
\text { of AMl }\end{array}$ & Rupture Site & $\begin{array}{l}\text { Diagnosis } \\
\text { method }\end{array}$ & $\pi$ & $\mathrm{PCl}$ & $\begin{array}{l}\text { surgical } \\
\text { repair }\end{array}$ & $\begin{array}{l}\text { percutaneous } \\
\text { closure }\end{array}$ & IABP/ECMO & Outcome (death) & $\begin{array}{l}\text { Onset Ml to } \\
\text { Death (Days) }\end{array}$ \\
\hline 1 & M & 64 & A & FWR & UCG & Yes & Yes & No & No & No & No & \\
\hline 2 & M & 74 & A & FWR & UCG & No & Yes & No & No & No & No & \\
\hline 3 & $\mathrm{~F}$ & 79 & A & VSR & UCG & No & Yes & No & No & Yes & Yes & 31 \\
\hline 4 & M & 83 & 1 & VSR & UCG & No & No & No & Yes & Yes & No & \\
\hline 5 & M & 83 & I & $F W R+V S R$ & UCG & No & Yes & No & No & Yes & Yes & 6 \\
\hline 6 & M & 69 & A & VSR & UCG & No & No & Yes & No & Yes & No & \\
\hline 7 & M & 68 & A & VSR & UCG & No & Yes & No & No & No & Yes & 4 \\
\hline 8 & $\mathrm{~F}$ & 65 & A & FWR & UCG & No & No & No & No & No & Yes & 1.0 \\
\hline 9 & $\mathrm{~F}$ & 87 & A & FWR & UCG & No & No & No & No & No & Yes & 0.4 \\
\hline 10 & F & 67 & A & VSR & UCG & No & Yes & No & No & No & Yes & 1.2 \\
\hline 11 & M & 69 & 1 & FWR & UCG & No & No & No & No & No & Yes & 0.4 \\
\hline 12 & $F$ & 76 & 1 & VSR & UCG & No & Yes & No & No & No & Yes & 7 \\
\hline 13 & $F$ & 58 & A & $F W R+V S R$ & UCG & No & No & No & No & No & Yes & 0.3 \\
\hline 14 & M & 78 & A & FWR & UCG & No & No & No & No & No & Yes & 2.3 \\
\hline 15 & M & 75 & A & VSR & UCG & No & Yes & No & No & Yes & Yes & 13 \\
\hline 16 & M & 46 & A & VSR & UCG & No & Yes & No & No & No & No & \\
\hline 17 & $F$ & 72 & A & FWR & UCG & No & No & No & No & No & Yes & 0.2 \\
\hline 18 & M & 59 & A & VSR & UCG & No & Yes & Yes & No & Yes & Yes & 53 \\
\hline 19 & M & 73 & A & VSR & UCG & No & No & No & Yes & Yes & No & \\
\hline 20 & M & 76 & A & VSR & UCG & No & No & No & No & Yes & Yes & 3.4 \\
\hline 21 & $\mathrm{~F}$ & 76 & A & VSR & UCG & No & Yes & No & No & No & Yes & 10 \\
\hline 22 & $\mathrm{~F}$ & 68 & 1 & FWR & UCG & No & Yes & No & No & No & Yes & 3.4 \\
\hline 23 & M & 63 & I & FWR & UCG & No & Yes & No & No & No & Yes & 6.2 \\
\hline 24 & $F$ & 63 & A & VSR & UCG & No & Yes & No & No & Yes & Yes & 15.5 \\
\hline 25 & $\mathrm{~F}$ & 66 & A & VSR & UCG & No & Yes & Yes & No & Yes & No & \\
\hline 26 & $F$ & 68 & $A+1$ & $F W R+V S R$ & UCG & Yes & No & No & No & Yes & Yes & 10.7 \\
\hline 27 & M & 59 & A & FWR & UCG & No & No & No & No & Yes & No & \\
\hline 28 & $F$ & 83 & A & FWR & UCG & No & No & No & No & No & Yes & 0.4 \\
\hline 29 & M & 49 & 1 & VSR & UCG & No & Yes & Yes & No & Yes & No & \\
\hline 30 & M & 55 & $A+1$ & FWR & UCG & No & No & No & No & No & No & \\
\hline 31 & M & 78 & A & FWR & UCG & No & No & No & Yes & No & Yes & 3.2 \\
\hline 32 & $F$ & 66 & A & FWR & UCG & No & No & No & Yes & No & Yes & 3 \\
\hline 33 & M & 61 & A & FWR & UCG & No & No & No & No & No & Yes & 4.4 \\
\hline 34 & M & 82 & 1 & FWR & UCG & No & No & No & No & Yes & Yes & 3 \\
\hline 35 & M & 72 & A & VSR & UCG & No & Yes & No & Yes & No & No & \\
\hline 36 & $M$ & 53 & A & FWR & UCG & No & No & No & Yes & No & Yes & 0.4 \\
\hline 37 & $F$ & 60 & A & VSR & UCG & No & Yes & No & Yes & No & No & \\
\hline 38 & $F$ & 51 & A & VSR & UCG & No & Yes & No & Yes & No & No & \\
\hline 39 & $F$ & 73 & a & VSR & UCG & No & No & Yes & No & No & No & \\
\hline 40 & $M$ & 58 & a & VSR & UCG & No & No & Yes & No & No & No & \\
\hline
\end{tabular}

$A$ anterior, $A M I$ acute myocardial infarct, ECMO extracorporeal membrane oxygenation, $\mathrm{F}$ female, $\mathrm{L}$ lateral, FWR free wall rupture, IABP intra-aortic balloon pumping, I inferior, $M$ male, $P C I$ percutaneous coronary intervention, $T$ thrombolytic therapy, UCG Ultrasonic Cardiogram, VSR ventricular septum rupture ${ }^{a}$ no information available 


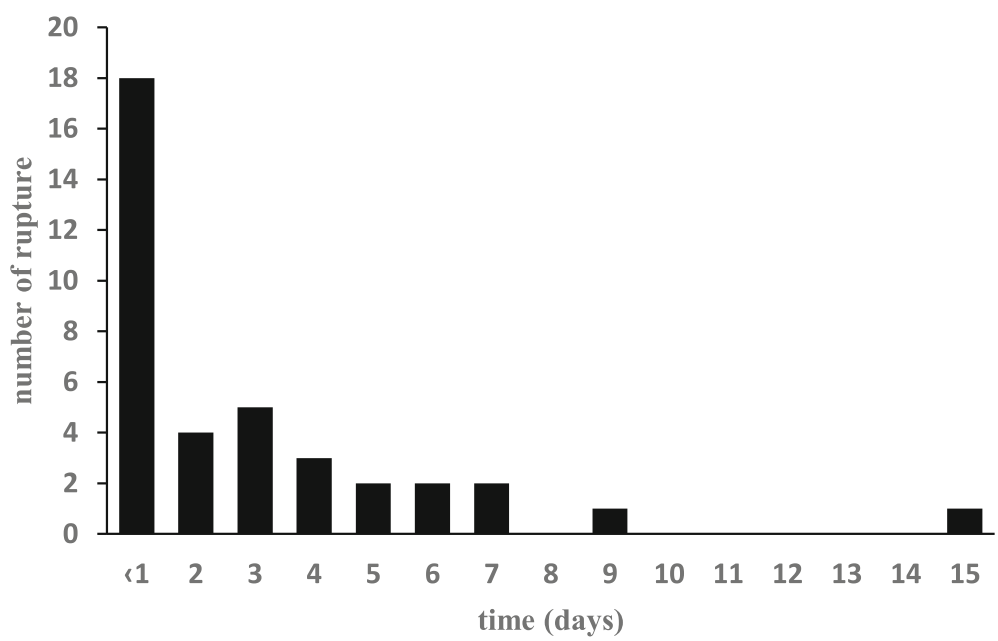

Fig. 2 The times from symptom onset to cardiac rupture diagnosis

2). The incidence of angina prior to the current MI was comparable between CR and CR-free groups.

\section{Clinical biochemical or angiographic findings}

Patients with CR exhibited higher counts of WBC and neutrophils at admission, and higher peak levels of CK$\mathrm{MB}$ and hs-CRP, and higher levels of D-D dimer and FDP (Fig. 3). There was a significant and positive correlation between peak CK-MB and peak hs-CRP $(r=$ 0.1991, $P<0.001, n=896$ ). Of 40 CR patients, 19 cases (47.5\%) underwent coronary angiography. There was no significant difference in patients without or with $\mathrm{CR}$ in characteristics of coronary lesion (Table 1).

\section{Risk factors associated with CR}

By multi-variables logistic regression models, age, female gender, peak CK-MB, peak hs-CRP and rural area were independent factors entered the regression model with OR between 2.49 to 12 (Fig. 4).

\section{Therapy and prognosis of patients with CR}

Of 885 CR-free STEMI patients, 293 patients underwent pPCI (32.2\%) and 480 patient received delay PCI (54.2\%). Among patients with CR, 12 cases underwent pPCI and 7 patients underwent delay PCI, with the rest 21 patients $(52.5 \%)$ did not receive PCI, a percentage higher than other STEMI patients without CR $(n=112$, $12.7 \%)$. Regarding the medications used, the proportions of the use of aspirin $(P=0.027), \mathrm{P} 2 \mathrm{Y} 12$ inhibitor $(P<$ $0.001)$, statin $(P<0.001), \beta$-blocker and ACEI/ARB $(P=$ $0.027)$ were significantly lower in the patients with $C R$ (Table 3). Except for medications and PCI, CR-related treatment was also applied to our CR patients including IABP $(n=14)$, ECMO $(n=2)$, open-chest surgery for $\operatorname{VSR}(n=6)$, or device closure therapy for VSR $(n=8)$.
Among 910 patients, a total of 48 patients died inhospital and 61 patients died within 60 days. Of $40 \mathrm{CR}$ patients, 2 patients (57.5\%) died in hospital and 25 (62.5\%) died within 60 days, contributing to $47.9 \%$ (23/ 48 ) in-hospital deaths and $41.0 \%$ (25/61) 60-day deaths. Other causes of in-hospital death were heart failure (10, $20.8 \%)$, arrhythmias $(9,18.8 \%)$ or cardiogenic shock (6, $12.5 \%)$. Similarly, non-CR reasons for 60 -day deaths consisted of heart failure (17, 27.9\%), arrhythmias (12, $19.7 \%)$ or cardiogenic shock $(7,11.5 \%)$. The post-STEMI survival was much lower in CR patients compared with CR-free patients (Fig. 5a). By survival analysis, openchest surgery, hemodynamics support or device closure therapy may be associated with improved prognosis (Fig. $5 b)$. The death rate was higher in patients with FWR was than these with VSR (Fig. 5c).

\section{CR time-course and influence of reperfusion in mice}

A total of 83 mice were operated with 39 mice were allocated in group-1, 21 mice in group- 2 and 23 mice in group-3. There were 7 mice died within $24 \mathrm{~h}$ after surgery due to surgical related reasons (bleeding, poor recovery from the procedure, $n=5)$ or acute heart failure $(n=2)$. The remaining mice $(n=36$ for group- $1, n=19$ for group-2, and $n=21$ for group-3) were included in observation of $\mathrm{CR}$ up to day-10 after surgery. At the end, all mice were euthanized and presence of cardiac infarct was confirmed by autopsy.

There were 17 deaths in group-1 occurring during day 3-6 post MI (Fig. 6a). Autopsy indicated all deaths due to LV free wall rupture with large amount of blood clot in the chest cage, albeit co-existence of acute heart failure was identified in 3 mice (i.e. pulmonary congestion, chest pleural effusion). In the two IR groups, one mouse died of acute heart failure at day 5 post surgery (Group3 ) and the rest of mice survived to the end of 
Table 2 Baseline clinical characteristics in 925 STEMI patients with and without CR

\begin{tabular}{|c|c|c|c|}
\hline & $\begin{array}{l}\text { Non-rupture } \\
(n=885)\end{array}$ & $\begin{array}{l}\text { Rupture } \\
(n=40)\end{array}$ & $P$ value \\
\hline Age (year) & $58.5 \pm 11.7$ & $68.2 \pm 10.1$ & $<0.001$ \\
\hline Male gender (\%) & $731(82.6 \%)$ & $23(57.5 \%)$ & 0.002 \\
\hline Socio-economic feature (rural area) & $446(50.4 \%)$ & $17(42.5 \%)$ & 0.041 \\
\hline Symptom-to-admission interval & & & 0.017 \\
\hline$<12 \mathrm{~h}$ & $324(36.6 \%)$ & $18(45.0 \%)$ & \\
\hline $12 \sim 24 \mathrm{~h}$ & $41(4.6 \%)$ & $5(12.5 \%)$ & \\
\hline$>24 h$ & $520(58.8 \%)$ & $8(42.5 \%)$ & \\
\hline \multicolumn{4}{|l|}{ Previous history } \\
\hline Diabetes & $127(14.4 \%)$ & $12(30.0 \%)$ & 0.012 \\
\hline Hypertension & $380(42.9 \%)$ & $26(65.0 \%)$ & 0.008 \\
\hline Alcohol consumption & $266(30.1 \%)$ & $0(0 \%)$ & $<0.001$ \\
\hline smoking & $587(66.3)$ & $12(30.0)$ & $<0.001$ \\
\hline Myocardial infarction & $53(6.0 \%)$ & $0(0 \%)$ & 0.162 \\
\hline Angina pectoris & $237(27.0 \%)$ & $6(15.0 \%)$ & 0.101 \\
\hline Coronary surgery & $24(2.7 \%)$ & $1(2.5 \%)$ & 0.936 \\
\hline \multicolumn{4}{|l|}{ Physical examination at admission } \\
\hline Systolic blood pressure (mmHg) & $123 \pm 20$ & $110 \pm 39$ & 0.001 \\
\hline Diastolic blood pressure (mmHg) & $77 \pm 13$ & $72 \pm 25$ & 0.047 \\
\hline Heart rate (bpm) & $76 \pm 14$ & $83 \pm 31$ & 0.004 \\
\hline Killip class & & & 0.002 \\
\hline 1 & $552(62.4 \%)$ & $11(45.8 \%)$ & \\
\hline$\|$ & $260(29.4 \%)$ & $6(15.0 \%)$ & \\
\hline III & $43(4.9 \%)$ & $3(7.5 \%)$ & \\
\hline IV & $30(3.4 \%)$ & $4(10.0 \%)$ & \\
\hline \multicolumn{4}{|l|}{ Ml localization } \\
\hline anterior & $359(40.6 \%)$ & $26(65 \%)$ & 0.002 \\
\hline inferior & $389(44 \%)$ & $8(20 \%)$ & 0.003 \\
\hline Infarct-related coronary artery & & & 0.417 \\
\hline Left anterior descending artery & $429(56.6 \%)$ & $17(68 \%)$ & \\
\hline Left circumflex artery & $58(7.7 \%)$ & $2(8 \%)$ & \\
\hline Right coronary artery & $266(35.1 \%)$ & $6(24 \%)$ & \\
\hline Left main trunk & $5(0.7 \%)$ & $0(0.0 \%)$ & \\
\hline Number of stenosed vessel & & & 0.854 \\
\hline 1 & $202(26.6 \%)$ & $4(21.1 \%)$ & \\
\hline 2 & $269(35.5 \%)$ & $7(36.8 \%)$ & \\
\hline 3 & 287 (37.9\%) & 8 (42.1\%) & \\
\hline
\end{tabular}

Data are mean (SD) or $\mathrm{n}(\%)$ unless otherwise stated. Killip class for $\mathrm{CR}$ patients was obtained prior to onset of rupture ( $n=24$ in rupture group). Among all STEMI patients, 773 patients underwent coronary angiography

experiment without onset of CR $(P<0.001$ for either of group- $2 / 3$ vs group- 1 ).

Influence of reperfusion on infarct size was determined in a separate cohort of mice. At $48 \mathrm{~h}$ after nonreperfused MI or IR (with 1 - or 4 -h ischemia, $n=6-8$ per group), the risk zone was comparable among groups (Fig. 6b). In non-reperfused MI group, almost entire ischemic myocardium become necrotic, whereas infarct size was significantly smaller in mice with 1-h IR. However, infarct size in 4-h IR mice was comparable to that of MI group (Fig. 6b).

\section{Discussion}

This retrospective study leads to the following main findings. First, the current in-hospital CR incidence is $1.4 \%$ in STEMI patients, but the real incidence is likely to be higher considering the pre-hospitalization onset of CR since a high proportion of CR occurred within day- 1 after STEMI. Second, the in-hospital and 60-day mortality of CR patients remains very high. Third, open-chest surgery, life support or device closure therapy are superior to medications to improve the prognosis of CR patients. Forth, the risk of CR is higher if STEMI patients are elderly, with large infarct size and high levels of inflammatory parameters. Finally, reperfusion completely eliminated CR in mice with MI.

The overall incidence of $\mathrm{CR}$ reported in the literature prior to the pPCI era was $10-20 \%$ [2], and the incidence of CR reported over the recent 10 years is around $1 \%$ [ 13, 14]. In the current study, the in-hospital incidence of CR was $1.4 \%$ in STEMI patients. Practically, the true incidence of $\mathrm{CR}$ is difficult to reach, as indicated by our study revealing that $19 / 40$ patients developed CR at admission. Such a high proportion of patients with early onset of $\mathrm{CR}$ highlights that $\mathrm{CR}$ remains a major challenge to modern cardiology and forms one of the main reasons of sudden cardiac death post-MI. A further hurdle added to this challenge is the current very low autopsy rate. In a recent study, Chen et al analyzed 11,234 STEMI patients from the 7 major hospitals in China and found that the incidence of CR was between 1 and 4\% among these hospitals [15]. Early reperfusion therapy could be the major factor responsible for the decline in the incidence of CR [1]. The results of mouse study provide a strong experimental evidence for the overt reduction of rupture in the last few decades with the initially increasing and currently routine use of primary $\mathrm{PCI}^{1}$.Although ACC/AHA [10] and ESC [11] Guidelines recommend reperfusion therapy within the first $12 \mathrm{~h}$ after symptom onset in all STEMI patients, some STEMI patients could not receive reperfusion therapy due to various reasons including delayed admission. Unfortunately, study has revealed that the proportion of patients in China who did not receive pPCI has not significantly improved over the last decade [15]. Low proportion of reperfusion therapy is likely one of the reasons for the onset of CR in-hospitalization.

Clinical reports prior to the reperfusion therapy era described the frequency of $\mathrm{CR}$ as two peaks: within $24 \mathrm{~h}$ 

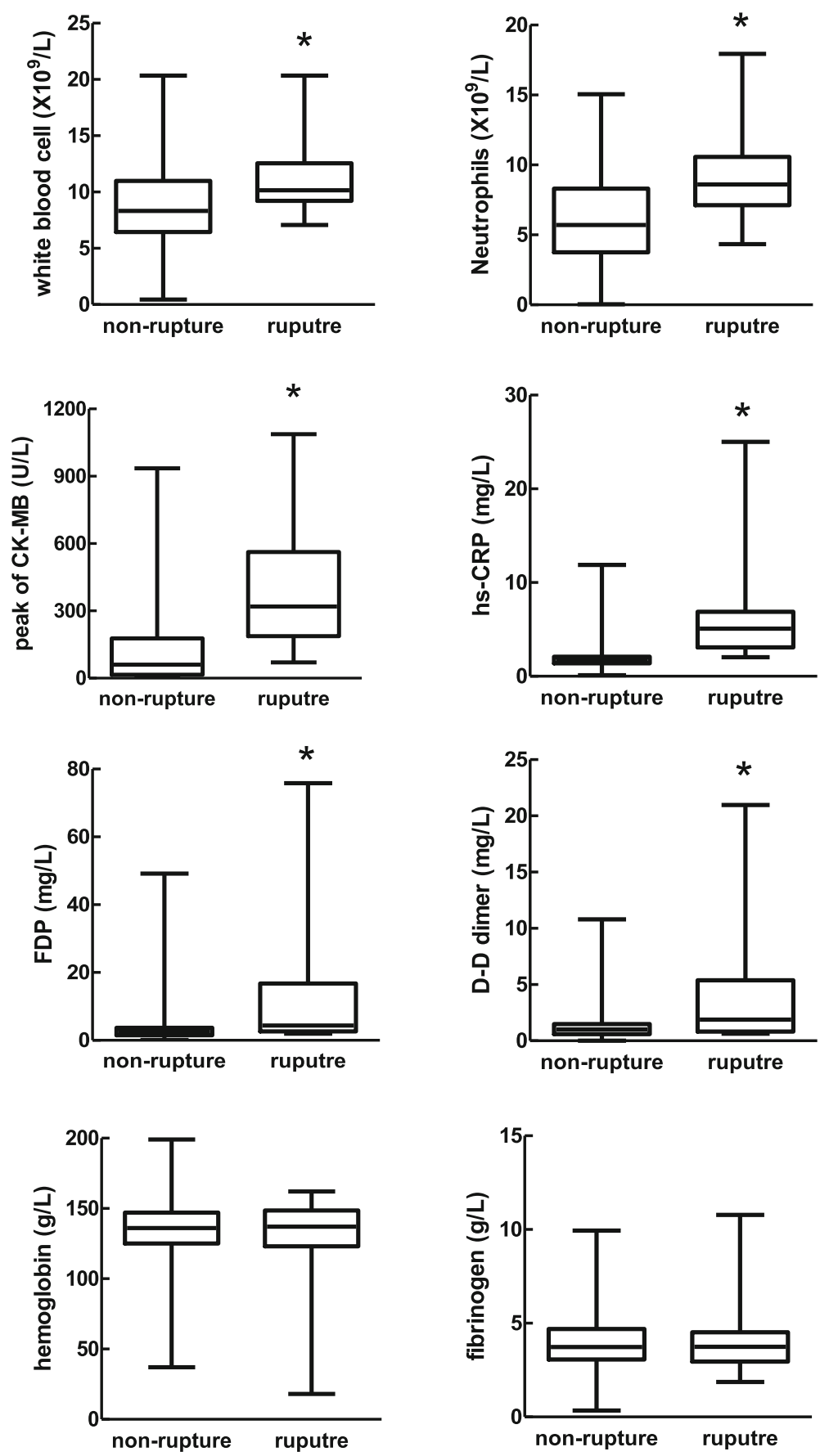

Fig. 3 Comparison of laboratory parameter between STEMI with or without cardiac rupture. CK-MB: creatine kinase-MB, hs-CRP: high sensitive Creactive protein, FDP: fibrinogen degradation product, WBC: white blood cell. ${ }^{*} P<0.05$ vs. STEMI without CR. Note: $n=11$ in rupture group for peak CK-MB and peak hs-CRP

and during 6-14 days after STEMI with nearly even proportion $[2,16]$. In our population study, whilst the early peak of CR remains, the late peak of CR seems blunted. Based on the Becker classification of CR [17], early CR is mainly type-I or type-II, whereas late rupture were typeIII associated with significant wall thinning and ventricular remodeling. The clinicopathological features of early and late rupture are different [18]. Early phase rupture is characterized by an abrupt slit-like tear in the infarcted myocardium, while late phase rupture exhibits infarct expansion and wall thinning [18].

While some studies indicated that reperfusion therapy is only associated with reduced incidence of late CR while showing limited benefit on the early CR $[16,19]$, it 
A

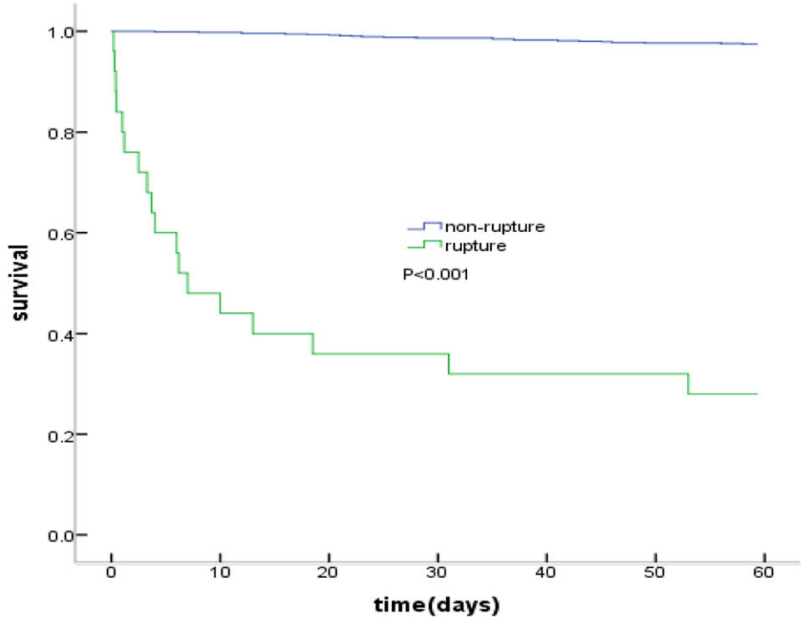

B

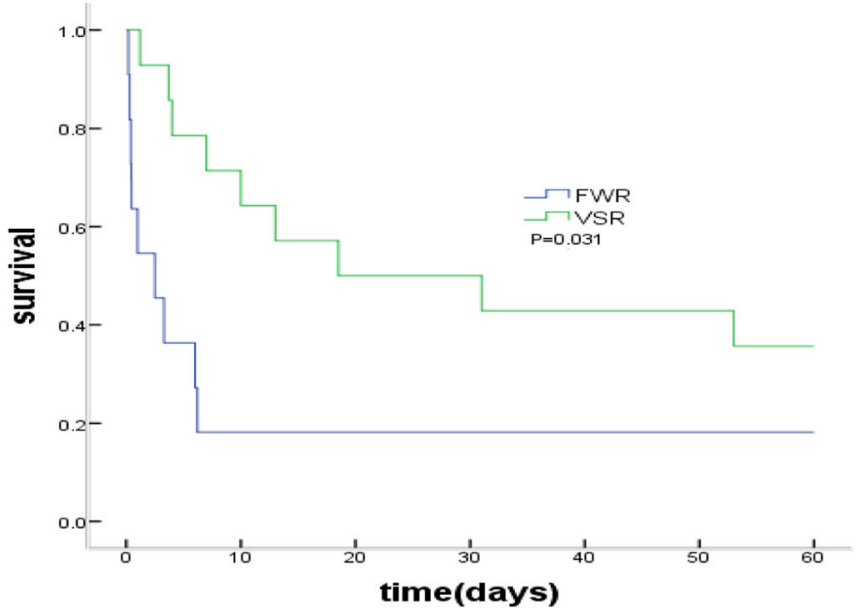

C

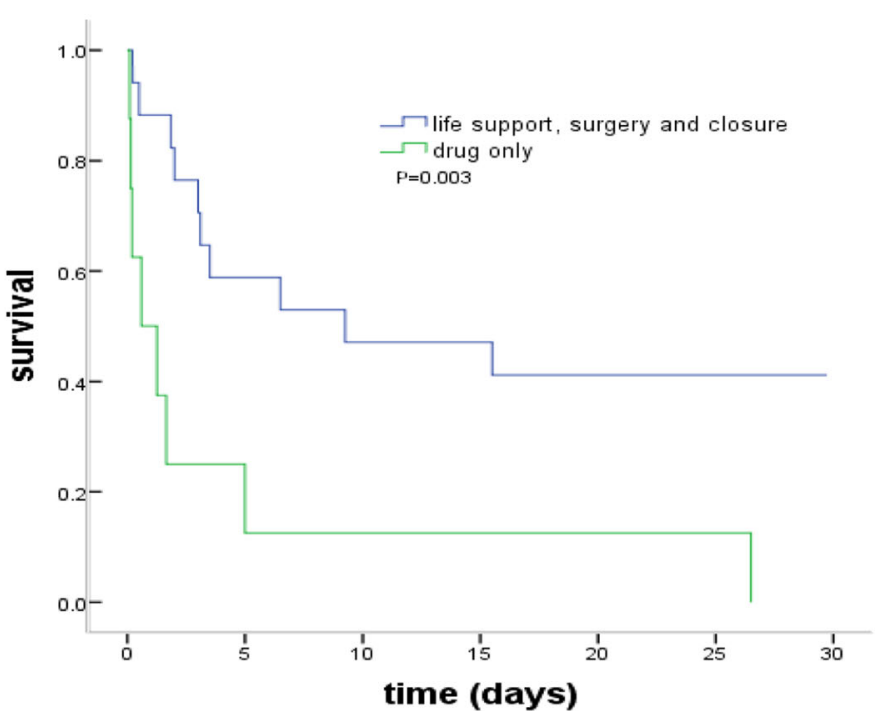

Fig. 4 Multivariate logistic regression analysis of risk factors and the incidence of cardiac rupture. CK-MB: creatine kinase-MB; hs-CRP: high sensitive C-reactive protein 
Table 3 Treatment characteristic in STEMI patients with or without cardiac rupture

\begin{tabular}{llll}
\hline & $\begin{array}{l}\text { Non-rupture } \\
(n=885)\end{array}$ & $\begin{array}{l}\text { Rupture } \\
(n=40)\end{array}$ & $P$ value \\
\hline Drugs & $858(97.0 \%)$ & $33(82.5 \%)$ & 0.006 \\
Aspirin & $850(96.0 \%)$ & $29(72.5 \%)$ & $<0.001$ \\
P2Y12 inhibitor & $793(89.6 \%)$ & $13(32.5 \%)$ & $<0.001$ \\
ACEl/ARB & $794(89.7 \%)$ & $15(37.5 \%)$ & $<0.001$ \\
B-blocker & $823(93.0 \%)$ & $13(32.5 \%)$ & $<0.001$ \\
Statins & & & $<0.001$ \\
PCl type & $283(32.0 \%)$ & $12(30 \%)$ & \\
primary PCl & $475(53.7 \%)$ & $7(17.5 \%)$ & \\
Delay PCl & $127(14.3 \%)$ & $21(52.5 \%)$ & \\
Non-PCl &
\end{tabular}

Data are $\mathrm{n}(\%) . A C E I / A R B$ angiotensin converting enzyme inhibitors or angiotensin-II receptor blockers, $\mathrm{PCl}$ percutaneous coronary intervention

is generally agreed that early reperfusion is able to reduce the rupture incidence [20]. In our CR patient study, 9 patients had early CR after pPCI. In contrast, our mouse study revealed that early or delayed reperfusion similarly abolished CR, albeit infarct size was reduced by early but not by delayed reperfusion. The benefit of delayed reperfusion is likely attributable to protection of other myocardial cellular populations and/or extracellular matrix [21]. Thus, the influence of reperfusion therapy in patients with MI requires further investigation. Whilst the mechanism for the strong protection against $\mathrm{CR}$, seen in mice with MI, remains to be illustrated. The infarct size might be reduced by reperfusion after $1 \mathrm{~h}$ ischemia in mice study [8], but not if ischemia last for $4 \mathrm{~h}$, it is clear that the protection associated with reperfusion not only pertain to cardiomyocytes, but also to non-cardiomyocyte matrix tissues within the ischemic zone, which provides tensile strength of the infarct wall $[8,22]$.

Our study showed that the mortality of $\mathrm{CR}$ remained to be very high $(64 \%$ within hospital and $72 \%$ within 60 days) relative to the earlier reports showing 100\% mortality for FWR [2] and approximately $90 \%$ for VSR without treatment [23], albeit the mortality of patients underwent surgery for correction of VSR varied between 20 and 60\% [12, 24]. Management of CR patients is complex and might require a variety of therapeutic approaches, including pharmacologic (include ACEI, $\beta$-blocker, intravenous nitrates, and hydralazine) and device-based therapies to achieve afterload reduction and hemodynamic stabilization. Whilst medical therapy and nonpharmacologic methods may only stabilize CR patients, the treatment of choice is closure of rupture site by surgical and catheter-based means [25, 26]. The outcome of operated CR patients is closely

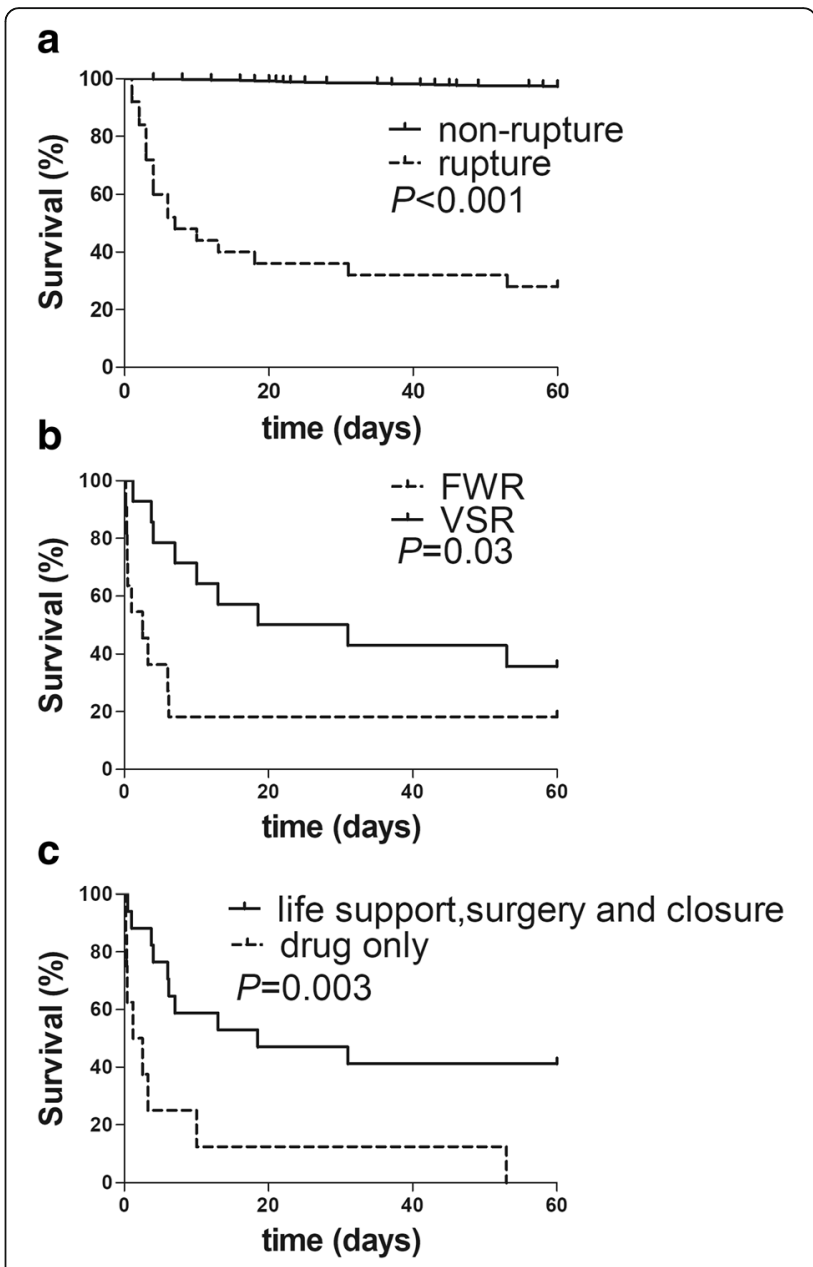

Fig. 5 Survival curves of patients with cardiac rupture. a compared between in STEMI patients with and without CR. $\mathbf{b}$ compared between FWR group and VSR group. c compared between drug treatment only and life support, surgery and closure in CR. FWR: free wall rupture, VSR: ventricular septum rupture

related to their hemodynamic state prior to the surgery. Emergency surgery for $\mathrm{CR}$ has been limited in our hospital due to the fact that patients with $\mathrm{CR}$ are often in extremis prior the surgery and many died suddenly. On the other hand, currently the percutaneous devices to primarily close VSR are only applicable to selected cases with simple defects (e.g. VSR less than $15 \mathrm{~mm}$ in diameter) with the optimal time approximately 3 weeks following MI. In our cohort, only 8 out of $40 \mathrm{CR}$ patients were suitable for percutaneous closure at 3 weeks after rupture occurred and they both survived over 60 days. Unfortunately, we experienced a high percentage of $\mathrm{CR}$ patients who refused further treatment because of reasons including critical conditions or high expenses.

In the current study, we revealed several independent risk factors of $\mathrm{CR}$ including female gender, old age, 

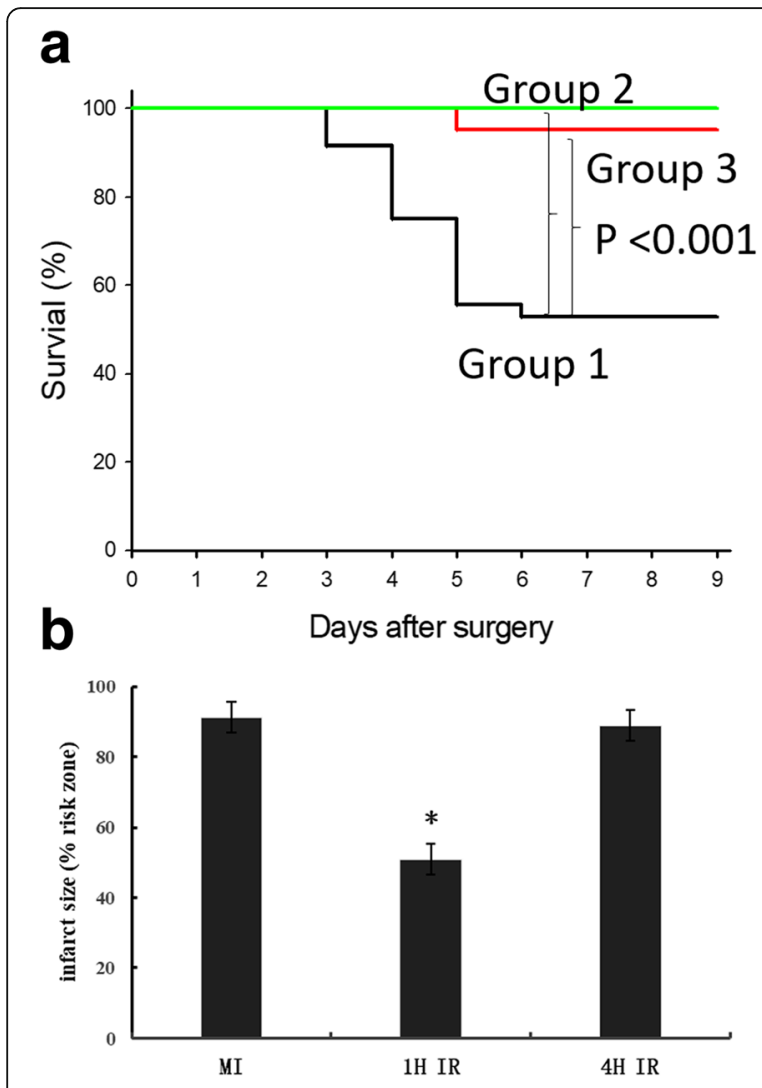

\section{C}

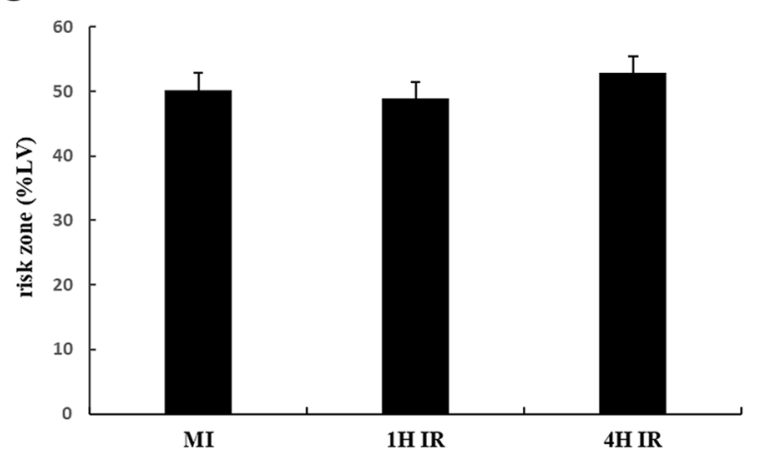

Fig. 6 Effect of reperfusion on the incidence of $C R$ and infarct size in mice. a Comparison of survival in mice with permanent coronary artery occlusion (Group-1, $n=36$ ), or reperfusion following 1-h (Group-2, $n=19$ ) or 4-h (Group 3, $n=21$ ) ischemia. b influence of reperfusion on infarct size in relation to ischemic duration. Note that infarct size was significantly reduced by early (i.e. 1-h ischemia) but not delayed (4-h ischemia) reperfusion. Infarct size date are mean \pm SEM. The group size was 6-8. ${ }^{*} P<0.01$ vs. non-reperfused $\mathrm{Ml}$ or 4 -h IR group

lower MI or angina history or higher heart rate, findings similar to earlier reports [2, 4, 27, 28]. Our study also added mechanistic insight by showing that both infarct size and the extent of inflammation are underlying factors for the onset of CR. The enzymatic index of infarct size, peak CK-MB [29], was one of the independent risk factors of CR in patients with STEMI. However, caution is required since many patients died before they arrived hospital with their infarct size was difficult to assess due to lack of serial measure of CM-MB and hence such relationship between infarct size and the risk of early onset of $\mathrm{CR}$ remains elusive. CRP is a non-specific and commonly used biomarker for inflammatory response. Hepatic production of CRP is increased upon stimulation by various cytokines derived from innate immune response evoked by myocardial ischemia and infarction [30]. We also observed a significant correlation between peak levels of CK-MB and CRP, implying a causative relation of the scale of infarct mass and subsequent inflammatory response. Indeed, others have also reported association of CRP levels and indexed infarct size [31, 32]. Previous clinical studies have shown that higher levels of CRP are associated with adverse prognosis in MI patients [33] including CR. Experimental studies on mice also showed the significance of infarct size in relation to loss of wall tensile strength and CR incidence [34]. Further support of inflammatory mechanism comes from our finding of higher inflammatory cell counts in CR relative to nonCR patients.

We found that the majority of CR patients (68\%) arrived hospital within $24 \mathrm{~h}$ after symptom onset, a proportion higher than that of non-CR STEMI patients, albeit by logistic regression analysis excluded the time from symptom onset to hospital as an independent risk factor. The likely reason for the early admission of $C R$ versus non-CR patients is due to the severity of symptom per se in patients with $\mathrm{CR}$ forcing them to seek medical assistance. Meanwhile, the rural location of residence of patients constitutes an independent risk factor of CR in our study. The possible explanation is that excessive time was required to arrive central hospitals to those patients who live in remote regions, and that common knowledge of MI was insufficient to those patients. Relevant to this is the limited availability of PCI especially pPCI in rural hospitals.

A significant body of knowledge has been generated by preclinical studies on the mechanism and therapeutic intervention of CR. These studies were entirely conducted in the mouse as the only laboratory species that develop CR post transmural MI like human patients [8, 22, 35]. Mechanistically, CR occurred in mice within a single onset peak timing (days 3-5) together with wall thinning and ventricular dilatation [22], simulating the human type-III rupture but without $\mathrm{CR}$ event within the first $24 \mathrm{~h}$, which differs from our clinical finding. In the mouse model of MI, the infarct size and scale of inflammatory response are pivotal determinants of CR, observations in keeping with the findings from the present study $[8,36]$. Regional inflammation results in accumulation of proteinases, particularly matrix 
metalloproteinase-9, responsible for the breakdown of existing collagen networks leading to reduced tensile strength of the infarcted wall [37-39]. Therapeutically, studies on mice have revealed successful inhibition of CR by anti-inflammatory therapies [40], or use of some currently routine medications like anti-platelet drugs, ARB or ACEI [35]. Collectively, our findings on patients with $C R$ are supported in part by studies in the mouse model of CR regarding significance of infarct size, age [41], inflammation $[38,40]$ and histopathology of typeIII CR $[8,22]$. Further research is required to illustrate the mechanism of early $\mathrm{CR}$ and test therapeutic interventions.

Our study has a few limitations that are worth to be discussed. This was a retrospective observational study consisting data from a single center, and hence had a limited number of CR cases. Some of laboratory or angiographic data were unable to obtain in those patients who had CR at admission. Furthermore, the diagnosis of $\mathrm{CR}$ was based on echocardiographic images and clinical characteristics, but without pathologic (autopsy) validation.

\section{Conclusion}

$\mathrm{CR}$ remains as a major cause of death in patients with $\mathrm{MI}$ and that the clinical features of CR patients such as risk factors, time-course, clinical presentation and mortality remain largely the same relative to the pre-PCI era. Furthermore, in mice with MI, reperfusion therapy completely prevent $\mathrm{CR}$.

\section{Abbreviations \\ CR: Cardiac rupture; FWR: Free wall rupture; VSR: Ventricular septum rupture; MI: Myocardial infarction; STEMI: ST-elevation myocardial infarction; PCl: Percutaneous coronary intervention; PPCl: Primary PCl; IR: Ischemia- reperfusion; hs-CRP: High-sensitive C-reactive protein; HB: Hemoglobin; WBC: White blood cell; FDP: Fibrinogen degradation products; CK- $M B$ : Creatine kinase-MB; ACEl: Angiotensin converting enzyme inhibitors; ARB: Angiotensin receptor blockers; IABP: Intra-aortic balloon pumping; ECMO: Extracorporeal membrane oxygenation; OR: Odds ratios; $\mathrm{Cl}$ : Confidence intervals}

\section{Acknowledgements}

Not applicable.

\section{Authors' contributions}

$\mathrm{QL}, \mathrm{LB}$ and $\mathrm{XD}$ designed the study, QL, JH, PL, YW, ZY and XD collected the data, QL and XD analyzed and interpreted the data, QL and XD prepared and revised the manuscript. All authors read and approved the final manuscript.

\section{Funding}

This study was funded by the Science and Technology Foundation of Shannxi Province (No: 2016HM-04, 2016JM-8038 and S2017-ZDYF-ZDCXL-SF0054). Qun Lu is also supported by Chinese Scholar Council scholarship (File No.201706285111). XJ Du's research is funded by the National Health and Medical Research Council of Australia and Nature Science Fund of China.

\section{Availability of data and materials}

All data generated or analyzed during this study are included in this published article.

\section{Ethics approval and consent to participate}

The protocol about patients was approved by the ethics committee of the First Affiliated Hospital of Xi'an Jiaotong University (Shaanxi 710061, China) and was in accordance with the Helsinki Declaration's guidelines. Informed consent was obtained for all participants and families. The mice were introduced from Jackson Laboratory (USA) and informed consent was obtained from this laboratory. These procedures about animal experiments were approved by a local animal ethics committee in compliance with the Australian Code for the Care and Use of Animals for Scientific Purposes (8th edition) and the ARRIVE guidelines.

\section{Consent for publication \\ Not applicable.}

\section{Competing interests}

The authors declare no competing interests.

\section{Author details}

'Department of Cardiovascular Medicine, First Affiliated Hospital, School of Medicine of Xi'an Jiaotong University, No.277 Yanta West Road, Xi'an, Shaanxi 710061, P.R. China. ${ }^{2}$ Experimental Cardiology Lab, Baker Heart and Diabetes Institute, 75 Commercial Road, Melbourne, Victoria 3004, Australia. ${ }^{3}$ College of Basic Medical Sciences, Xi'an Jiaotong University Health Science Center, Xi'an, Shannxi Province, P.R. China.

Received: 29 April 2020 Accepted: 25 August 2020

Published online: 10 September 2020

\section{References}

1. Figueras J, Alcalde O, Barrabes JA, Serra V, Alguersuari J, Cortadellas J, Lidon RM. Changes in hospital mortality rates in 425 patients with acute STelevation myocardial infarction and cardiac rupture over a 30-year period. Circulation. 2008;118:2783-9.

2. Pohjola-Sintonen S, Muller JE, Stone PH, Willich SN, Antman EM, Davis VG, Parker CB, Braunwald E. Ventricular septal and free wall rupture complicating acute myocardial infarction: experience in the multicenter investigation of limitation of infarct size. Am Heart J. 1989;117:809-18.

3. Honda S, Asaumi Y, Yamane T, Nagai T, Miyagi T, Noguchi T, Anzai T, Goto Y, Ishihara M, Nishimura K, Ogawa H, Ishibashi-Ueda H, Yasuda S. Trends in the clinical and pathological characteristics of cardiac rupture in patients with acute myocardial infarction over 35 years. J Am Heart Assoc. 2014;3:e000984.

4. Becker RC, Hochman JS, Cannon CP, Spencer FA, Ball SP, Rizzo MJ, Antman EM. Fatal cardiac rupture among patients treated with thrombolytic agents and adjunctive thrombin antagonists: observations from the thrombolysis and thrombin inhibition in myocardial infarction 9 study. J Am Coll Cardiol. 1999:33:479-87.

5. French JK, Hellkamp AS, Armstrong PW, Cohen E, Kleiman NS, O'Connor CM, Holmes DR, Hochman JS, Granger CB, Mahaffey KW. Mechanical complications after percutaneous coronary intervention in ST-elevation myocardial infarction (from APEX-AMI). Am J Cardiol. 2010;105:59-63.

6. Honan MB, Harrell FE Jr, Reimer KA, Califf RM, Mark DB, Pryor DB, Hlatky MA. Cardiac rupture, mortality and the timing of thrombolytic therapy: a metaanalysis. J Am Coll Cardiol. 1990;16:359-67.

7. Becker RC, Charlesworth A, Wilcox RG, Hampton J, Skene A, Gore JM, Topol EJ, Investigators aftLAoTE. Cardiac rupture associated with thrombolytic therapy: Impact of time to treatment in the late assessment of thrombolytic efficacy (LATE) study. J Am Coll Cardiol. 1995;25:1063-8.

8. Gao XM, Xu Q, Kiriazis H, Dart AM, Du XJ. Mouse model of post-infarct ventricular rupture: time course, strain- and gender-dependency, tensile strength, and histopathology. Cardiovasc Res. 2005;65:469-77.

9. Gao XM, Wang BH, Woodcock E, Du XJ. Expression of active alpha (1B)adrenergic receptors in the heart does not alleviate ischemic reperfusion injury. J Mol Cell Cardiol. 2000;32:1679-86.

10. Levine GN, Bates ER, Blankenship JC, Bailey SR, Bittl JA, Cercek B, Chambers CE, Ellis SG, Guyton RA, Hollenberg SM, Khot UN, Lange RA, Mauri L, Mehran R, Moussa ID, Mukherjee D, Ting HH, O'Gara PT, Kushner FG, Ascheim DD, Brindis RG, Casey DE Jr, Chung MK, de Lemos JA, Diercks DB, Fang JC, Franklin BA, Granger CB, Krumholz HM, Linderbaum JA, Morrow DA, Newby LK, Ornato JP, Ou N, Radford MJ, Tamis-Holland JE, Tommaso CL, Tracy CM, Woo YJ, DX. Z. 2015 ACC/AHA/SCAl focused update on primary 
percutaneous coronary intervention for patients with ST-elevation myocardial infarction: an update of the 2011 ACCF/AHA/SCAI guideline for percutaneous coronary intervention and the 2013 ACCF/AHA guideline for the management of ST-elevation myocardial infarction. J Am Coll Cardiol. 2016;67:1235-50

11. Steg PG, James SK, Atar D, Badano LP, Blömstrom-Lundqvist C, Borger MA Di Mario C, Dickstein K, Ducrocq G, Fernandez-Aviles F, Gershlick AH, Giannuzzi P, Halvorsen S, Huber K, Juni P, Kastrati A, Knuuti J, Lenzen MJ, Mahaffey KW, Valgimigli M, van 't Hof A, Widimsky P, D. Z. ESC Guidelines for the management of acute myocardial infarction in patients presenting with ST-segment elevation: The Task Force on the management of STsegment elevation acute myocardial infarction of the European Society of Cardiology (ESC). Eur Heart J. 2012;33:2569-2619.

12. Kutty RS, Jones N, Moorjani N. Mechanical complications of acute myocardial infarction. Cardiol Clin. 2013;31:519-31 vii-viii.

13. Rencuzogullari I, Cagdas M, Karabag Y, Karakoyun S, Yesin M, Gursoy MO, Seyis S, Artac I, llis D, Efe SC, Tanboga IH. Association of the SYNTAX score II with cardiac rupture in patients with ST-segment elevation myocardial infarction undergoing a primary percutaneous coronary intervention. Coron Artery Dis. 2018;29:97-103

14. Chang RY, Tsai HL, Hsiao PG, Tan CW, Lee CP, Chu IT, Chen YP, Chen CY Comparison of the risk of left ventricular free wall rupture in Taiwanese patients with ST-elevation acute myocardial infarction undergoing different reperfusion strategies: A medical record review study. Medicine (Baltimore). 2016:95:e5308.

15. Qian G, Jin RJ, Fu ZH, Yang YQ, Su HL, Dong W, Guo J, Jing J, Guo YL, Chen YD. Development and validation of clinical risk score to predict the cardiac rupture in patients with STEMI. Am J Emerg Med. 2017;35:589-93.

16. Nakamura F, Minamino T, Higashino $Y$, Ito H, Fujii K, Fujita T, Nagano M, Higaki J, Ogihara T. Cardiac free wall rupture in acute myocardial infarction: ameliorative effect of coronary reperfusion. Clin Cardiol. 1992;15:244-50.

17. Becker RC, Gore JM, Lambrew C, Weaver WD, Rubison RM, French WJ, Tiefenbrunn AJ, Bowlby L, Rogers WJ. A composite view of cardiac rupture in the United States National Registry of myocardial infarction. J Am Coll Cardiol. 1996;27:1321-6.

18. Nakatsuchi Y, Minamino T, Fujii K, Negoro S. Clinicopathological characterization of cardiac free wall rupture in patients with acute myocardial infarction: difference between early and late phase rupture. Int J Cardiol. 1994:47:S33-8.

19. Nozoe M, Sakamoto T, Taguchi E, Miyamoto S, Fukunaga T, Nakao K. Clinical manifestation of early phase left ventricular rupture complicating acute myocardial infarction in the primary PCl era. J Cardiol. 2014;63:14-8.

20. Bates ER. Reperfusion therapy reduces the risk of myocardial rupture complicating ST-elevation myocardial infarction. J Am Heart Assoc. 2014;3: e001368.

21. Du XJ. Post-infarct cardiac injury, protection and repair: roles of noncardiomyocyte multicellular and acellular components. Sci China Life Sci. 2018;61:266-76.

22. Gao XM, White DA, Dart AM, Du XJ. Post-infarct cardiac rupture: recent insights on pathogenesis and therapeutic interventions. Pharmacol Ther 2012:134:156-79.

23. Poulsen SH. Praestholm M, Munk K, Wierup P, Egeblad H, JE. N-K. ventricular septal rupture complicating acute myocardial infarction: clinical characteristics and contemporary outcome. Ann Thorac Surg. 2008;85:1591-6.

24. Cinq-Mars A, Voisine $P$, Dagenais $F$, Charbonneau $E$, Jacques $F$, Kalavrouziotis D, Perron J, Mohammadi S, Dubois M, Le Ven F, Poirier P, O'Connor K, Bernier M, Bergeron S, Senechal M. Risk factors of mortality after surgical correction of ventricular septal defect following myocardial infarction: retrospective analysis and review of the literature. Int J Cardiol. 2016;206:27-36.

25. Baldasare MD, Polyakov M, Laub GW, Costic JT, McCormick DJ, Goldberg S. Percutaneous repair of post-myocardial infarction ventricular septal defect: current approaches and future perspectives. Tex Heart Inst J. 2014;41:613-9.

26. Lin CH, Balzer D, Lasala J. Transcatheter closures of a postinfarction ventricular septal defect and late ventricular pseudoaneurysm. J Invasive Cardiol. 2010;22:E132-7.

27. Figueras J, Juncal A, Carballo J, Cortadellas J, Soler JS. Nature and progression of pericardial effusion in patients with a first myocardial infarction: relationship to age and free wall rupture. Am Heart J. 2002; $144: 251-8$.
28. Lopez-Sendon J, Gurfinkel EP, Lopez de Sa E, Agnelli G, Gore JM, Steg PG, Eagle KA, Cantador JR, Fitzgerald G, Granger CB, Global Registry of Acute Coronary Events I Factors related to heart rupture in acute coronary syndromes in the Global Registry of Acute Coronary Events. Eur Heart J 2010;31:1449-1456.

29. Grande P, Hansen BF, Christiansen C, Naestoft J. Acute myocardial infarct size estimated by serum CK-MB determinations: clinical accuracy and prognostic relevance utilizing a practical modification of the isoenzyme approach. Am Heart J. 1981;101:582-6.

30. Jahn J, Hellmann I, Maass M, Giannitsis E, Dalhoff K, Katus HA. Timedependent changes of hs-CRP serum concentration in patients with non-ST elevation acute coronary syndrome. Herz. 2004;29:795-801.

31. Barrett TD, Hennan JK, Marks RM, Lucchesi BR. C-reactive-protein-associated increase in myocardial infarct size after ischemia/reperfusion. J Pharmacol Exp Ther. 2002;303:1007-13.

32. De Sutter J, De Buyzere M, Gheeraert P, Van de Wiele C, Voet J, De Pauw M, Dierckx R, De Backer G, Taeymans Y. Fibrinogen and C-reactive protein on admission as markers of final infarct size after primary angioplasty for acute myocardial infarction. Atherosclerosis. 2001;157:189-96.

33. Anzai T, Yoshikawa T, Shiraki H, Asakura Y, Akaishi M, Mitamura H, Ogawa S. C-reactive protein as a predictor of infarct expansion and cardiac rupture after a first Q-wave acute myocardial infarction. Circulation. 1997:96:778-84.

34. Gao XM, Ming Z, Su Y, Fang L, Kiriazis H, Xu Q, Dart AM, Du XJ. Infarct size and post-infarct inflammation determine the risk of cardiac rupture in mice. Int J Cardiol. 2010;143:20-8.

35. Gao XM, Tsai A, Al-Sharea A, Su Y, Moore S, Han LP, Kiriazis H, Dart AM, Murphy AJ, Du XJ. Inhibition of the renin-angiotensin system post myocardial infarction prevents inflammation-associated acute cardiac rupture. Cardiovasc Drugs Ther. 2017;31:145-56.

36. Heymans S, Luttun A, Nuyens D, G T, Creemers E, Moons L, Dyspersin GD, Cleutjens JPM, SHIPLEY M, Angellilo A, Levi M, NÜBe O, Baker A, Keshet E, Lupu F, Herbert JM, Smits JFM, Shapiro SD, Baes M, Borgers M, Collen D, Daemen MJAP, P C Inhibition of plasminogen activators or matrix metalloproteinases prevents cardiac rupture but impairs therapeutic angiogenesis and causes cardiac failure. Nat Med 1999:5:1135-1142.

37. Fang L, Gao XM, Moore XL, Kiriazis H, Su Y, Ming Z, Lim YL, Dart AM, Du XJ. Differences in inflammation, MMP activation and collagen damage account for gender difference in murine cardiac rupture following myocardial infarction. J Mol Cell Cardiol. 2007;43:535-44.

38. Tao ZY, Cavasin MA, Yang F, Liu YH, Yang XP. Temporal changes in matrix metalloproteinase expression and inflammatory response associated with cardiac rupture after myocardial infarction in mice. Life Sci. 2004;74:1561-72.

39. Matsumura S, Iwanaga S, Mochizuki S, Okamoto H, Ogawa S, Y. O. Targeted deletion or pharmacological inhibition of MMP-2 prevents cardiac rupture after myocardial infarction in mice. J Clin Invest. 2005;115:599-609.

40. Seropian IM, Toldo S, Van Tassell BW, Abbate A. Anti-inflammatory strategies for ventricular remodeling following ST-segment elevation acute myocardial infarction. J Am Coll Cardiol. 2014:63:1593-603.

41. Yang Y, Ma Y, Han W, Li J, Xiang Y, Liu F, Ma X, Zhang J, Fu Z, Su YD, Du XJ, Gao XM. Age-related differences in postinfarct left ventricular rupture and remodeling. Am J Physiol Heart Circ Physiol. 2008;294:H1815-22.

\section{Publisher's Note}

Springer Nature remains neutral with regard to jurisdictional claims in published maps and institutional affiliations.

Ready to submit your research? Choose BMC and benefit from:

- fast, convenient online submission

- thorough peer review by experienced researchers in your field

- rapid publication on acceptance

- support for research data, including large and complex data types

- gold Open Access which fosters wider collaboration and increased citations

- maximum visibility for your research: over $100 \mathrm{M}$ website views per year

At $\mathrm{BMC}$, research is always in progress.

Learn more biomedcentral.com/submission 